\title{
Effective Factors on Reducing the Number of Spectators in Iran Football Premier League
}

\author{
${ }^{1}$ Amir Reza Khadem Azghadi ${ }^{*}{ }^{1}$ Mohammad Reza Boroumand, ${ }^{1}$ Mohammad Hosein Salari \\ ${ }^{1}$ Department of Sport Management and Media, Faculty of Sport Sciences, Shahid Beheshti University, Tehran, Iran.
}

\begin{abstract}
Because of reducing the number of spectators of football premier league, this study is seeking for identifying factors put the most impact on this decline. The statistical population consisted of all spectators in Iran football premier league in 2015-16, out of which 395 spectators were randomly selected as the research samples. The data were collected via a researcher-made questionnaire. The first part of the questionnaire included demographic information and the second part, at 6 aspects, includes 35 questions analyzing the reasons for reducing the number of spectators in Iran's football Premier League. For analyzing data, it was used from first and second order confirmatory factor analysis based on structural equations through using SPSS 20 and LISREL 8.8 software. The results of first order confirmatory factor analysis showed that the measurement model of factors affecting on reducing the number of spectators of football premier league is an appropriate model and model parameters are significant. All factors are approved as effective variables on reducing the number of spectators of football premier league. The results also showed that the second order measurement model of effective factors on reducing the number of spectators of football premier league are also appropriate, and economic, facilitative, administrative, technical, cultural-social, and personal-family respectively put the most effects on reducing the number of spectators of football premier league. It is suggested for the sport marketers to analyze identified factors in this research and develop applicable strategies and guidelines for them.
\end{abstract}

KEY WORDS: Reducing the Number of Spectators, Football Premier League of Iran.

\section{INTRODUCTION}

The industry of professional sporting events is increasingly turning into a social trend towards the presence of people as spectators at the sporting events all over the world (1). There are many forms of endorsement and support behavior of clubs among which the most important one is the presence of spectators in the stadium (2). According to Hansen and Gauthier (1989), the most important factor in attracting investment in professional sports and championships is to increase the number of spectators who indirectly obtain earnings for clubs and professional leagues through directly purchasing the tickets of the tournament (3) and in addition to gain identity to sports leagues, they have a major contribution in the revenue via attracting sponsors and sale of television rights and other auxiliary services (4). In their study, Theodorakis et al. (2009) reported that Manchester United football team earned 157.5 million Euros (including day tickets, season

*. Corresponding Author: 
tickets and membership) from entrance booths and 29 home games in the season 2006-2007 which is equal to $44 \%$ of its total income in the season (5) while in Iran, ticketing provides the small source of clubs' income and the financial costs of clubs are mostly funded by state agencies (6). The study on Iran football premier league by Ghorbani (2015) showed that in recent years, the number of spectators in stadiums have experienced a significant reduction in a way that the number of spectators dropped more than $50 \%$ within three seasons of 2012-2013 to 20142015, and in five seasons (2010-2011 to 20142015), $70 \%$ of the capacity of the stadium was empty and in the season 2014-2015, it reached $81.3 \%$ and only 18.7 of the capacity of stadiums were filled by the spectators (7). The lack of significant welcome of sport fans is one of businesses' obstacles for financial supports from sports and teams (8). A variety of factors affect the number of spectators of sporting events among which technical factors, economic factors, demographic factors, social and cultural factors, management staff and necessary facilities for spectators interested in attending the clubs can be mentioned. The attractiveness of a match depends on the importance of the play, the skill level of athletes and its position in a league or tournament (9). Economic factors are also divided into two controllable and uncontrollable categories. For example, ticket price and level of income are controllable and uncontrollable, respectively (10). Demographic variables such as age, sex, education, occupation, income level, etc. also affect the presence of individuals at sporting events (11). Access to stadium, stadium beauty, stadium cleanliness, comfortable seats and safety and security of stadiums are also very important factors in attracting spectators (12). Thus, due to reducing the number of spectators in Iran Football Premier League in recent years, understanding the factors with the greatest impact on the decline seems necessary.

\section{MATERIALS AND METHODS}

With regard to the purpose, the present study is applied and in terms of data collection, it is descriptive-survey research.

Participants. The statistical population consisted of all spectators in Iran football premier league in 2015-16. The study samples were randomly selected as 384 individuals according to Morgan table (for large populations) so that considering the possible sample loss, 435 questionnaires were distributed and 427 questionnaires were eventually collected. A total of 395 questionnaires were finally analyzed.

Tolls. The data were collected via a researcher-made questionnaire. For this purpose, after collecting 438 articles and selecting and examining 177 studies, 6 national research projects, 26 books and interviews with 8 experts and executives in the field of football, the research team extracted 109 questions. Then, they selected 62 questions related to the subject. After evaluating the face validity, Content Validity Ratio (CVR) was used to confirm the content validity. In addition, we sent the questions to 10 experts in the field of sport management in the form of expert questionnaire. By examining every single question by the formula related to CVR, the validity of 35 questions was confirmed under the rubric of 6 variables. The mentioned questionnaire was made up of two parts: The first part included demographic information including age, level of education, occupation, marital status, family income and the way to buy ticket. The second part reviewed the reasons for the reduction in the number of spectators of Iran Premium League in six dimensions including economic factors (questions 1 to 5), managerial factors (questions 5 to 11 ), technical factors (questions 11 to 17 ), cultural-social factors (questions 17 to 23), personal-familial factors (questions 23 to 27) and facility-equipment factors (questions 27 to 35). In order to investigate the reliability of the questionnaire, 35 questionnaires were distributed among the spectators. The reliability was calculated using Cronbach's alpha coefficient. The results of Cronbach's alpha coefficient for all the main dimensions showed that the questionnaire enjoyed high degree of reliability $(\alpha>0.7)$. After having the questionnaire confirmed and obtaining recommendations from the university to Iranian Football League Organization, we received entry permit to the football stadiums to distribute the questionnaires among the spectators and gather the required data. We motivated the spectators to complete the questionnaires by incentives including 
equipment donated for cheering their favorite teams and buying tickets for some of them.

Statistical Analysis. Skewness and kurtosis tests were used for the normality of the data. Given that the skewness and kurtosis of all data were between 2 and 2, data distribution was normal; therefore, parametric statistics were used to analyze the data. $\mathrm{KMO}$ and Bartlett's tests were also used to measure the sampling adequacy indicator (Table 1).

Table 1. KMO and Bartlett's test

\begin{tabular}{ccc}
\hline Kaiser-Meyer-Olkin Measure (KMO) & 0.710 \\
\hline \multirow{3}{*}{ Bartlett's Test } & Chi square & 389.669 \\
\cline { 2 - 3 } & Degree of freedom & 36 \\
\cline { 2 - 3 } & significance & 0.001 \\
\hline
\end{tabular}

According to Table 1, given that the KMO index value is higher than $0.6(0.071)$, the sampling adequacy indicator shows the proper value in the calculation. Also, given that the chisquare coverage area (0.001) for Bartlett's test is lower than 0.05 , the status of the index is fit and that there is no significant relationship between the variables.

Confirmatory factor analysis based on structural equation model was used to test and confirm the sub-scales and variables of the questionnaire. In other words, construct validity (factor) of the questionnaire was used. In order to evaluate the effect of the confirmed first-order factors with the higher order variable, secondorder confirmatory factor analysis was used. For statistical calculations, SPSS 20 and LISREL 8.8 software were run.

\section{RESULTS}

Demographic findings showed that $83.55 \%$ of the spectators were less than 30 years of age. $69.04 \%$ were single, $46.6 \%$ had school diploma and $47.6 \%$ were students (school and college students). In terms of income, $82 \%$ of spectators had income of less than 600 dollars a month. $41 \%$ of the spectators had the desire to buy ticket via the Internet, whereas $40 \%$ had the desire to buy ticket in stadium box office. Only $3.3 \%$ liked to buy the tickets for the while season. The results of the first-order factor analysis model of the effective factors on reducing the number of spectators of Iran football Premier League are presented in Table 2.

The results of the first-order confirmatory factor analysis revealed that the measurement model of effective factors on reducing the number of spectators of Iran football Premier League was fit and all the numbers and parameters of the model were significant. In addition, the effect of all components as effective variables on reducing the number of spectators of Iran football Premier League was confirmed.

Measurement model fit indices are presented in Table 3. They indicate that the measurement model is fit.

As can be seen in Table 3, index $\chi^{2 / D F}$ is smaller than 3, RMSEA index with a value of 0.071 is less than 0.08 , PNFI with a value of 0.62 is above the cut-off point i.e. 0.5 and all NFI, RFI, and CFI indicators are more than 0.90 which all represent excellent and reasonable fit of the first order factors in reducing the number of spectators of Iran football Premier League. Hence, the confirmatory factor analysis substantiated that the model had an acceptable and appropriate validity.

The results of the second-order confirmatory factor analysis of the effective factors on reducing the number of spectators of Iran football Premier League in two standard and significant coefficient modes are given in Figures 1 and 2 below.

The results revealed that the second-order measurement model of effective factors on reducing the number of spectators of Iran football Premier League was fit and all the numbers and parameters of the model were significant and that economic factors, facility-equipment factors, managerial factors, technical factors, culturalsocial factors, and personal-familial factors had the greatest impact on the reduction of the number of spectators of Iran football Premier League. Model fit indices are presented in Table 4.

As can be seen in Table 4, the value of index $\chi 2 / \mathrm{DF}$ is smaller than 3 , RMSEA index with a value of 0.71 is less than 0.1 , PNFI with a value of 0.59 is above the cut-off point i.e. 0.5 and all NFI, RFI, and CFI indicators are more than 0.90 which all represent excellent and reasonable fit of the second order factors in reducing the number of spectators of Iran football Premier League. Hence, the confirmatory factor analysis substantiated that the model had an acceptable and appropriate validity. 
Table 2. The results of first-order factor analysis of the effective factors on reducing the number of spectators of Iran football Premier League

\begin{tabular}{|c|c|c|c|c|}
\hline Variable & Code & Component & $\begin{array}{c}\text { Confirmatory } \\
\text { factor (r) }\end{array}$ & $\begin{array}{c}\mathrm{t}- \\
\text { value }\end{array}$ \\
\hline \multirow{4}{*}{ 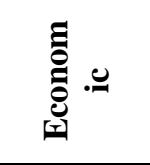 } & E1 & High prices of the tournament tickets & 0.73 & 10.87 \\
\hline & $\mathbf{E 2}$ & High cost of transportation to the stadium & 0.65 & 7.37 \\
\hline & $\mathbf{E 3}$ & Expensive food and beverages in the stadium & 0.67 & 11.19 \\
\hline & $\mathbf{E 4}$ & Low levels of family income & 0.61 & 8.34 \\
\hline \multirow{6}{*}{ 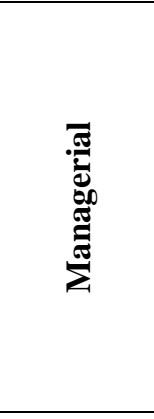 } & M1 & $\begin{array}{l}\text { Holding the competition at the wrong time (working days, in the } \\
\text { middle of the week, bad hours ...) }\end{array}$ & 0.56 & 9.44 \\
\hline & M2 & $\begin{array}{l}\text { Inappropriate treatment of the Executive Force deployed in the } \\
\text { stadium }\end{array}$ & 0.41 & 10.30 \\
\hline & M3 & Lack of presence of women in stadiums & 0.50 & 10.06 \\
\hline & M4 & $\begin{array}{l}\text { Absence of Directors with specialty in football at the club's top } \\
\text { management }\end{array}$ & 0.51 & 9.62 \\
\hline & M5 & $\begin{array}{l}\text { Lack of appropriate facilities for spectators in games away from } \\
\text { home }\end{array}$ & 0.69 & 10.11 \\
\hline & M6 & Poor status of tournament ticket sales & 0.58 & 7.58 \\
\hline \multirow{6}{*}{ 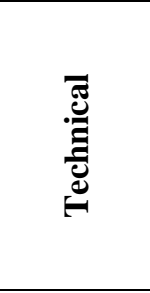 } & F1 & The absence of star players in the favorite team & 0.60 & 11.19 \\
\hline & F2 & Poor performance of the Favorite team & 0.56 & 11.08 \\
\hline & F3 & Lack of the beauty of the game and low technical level & 0.63 & 9.92 \\
\hline & F4 & Absence of outstanding foreign coaches and players in the league & 0.43 & 11.03 \\
\hline & F5 & Poor judgment of some referees throughout the season & 0.67 & 5.91 \\
\hline & F6 & $\begin{array}{l}\text { Poor performance of national football teams in international } \\
\text { competitions }\end{array}$ & 0.53 & 7.21 \\
\hline \multirow{6}{*}{ 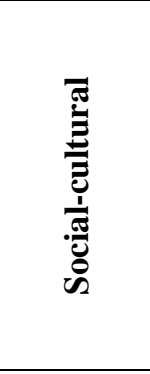 } & FR1 & Lack of leisure activities utility to start the game and at half & 0.69 & 5.80 \\
\hline & FR2 & $\begin{array}{l}\text { Lack of contest, sweepstakes and free gifts in the stadium } \\
\text { tournament venue }\end{array}$ & 0.41 & 3.09 \\
\hline & FR3 & Conflict and violence in stadiums & 0.40 & 8.19 \\
\hline & FR4 & Obscenities and profanities and vulgar words in stadiums & 0.58 & 7.34 \\
\hline & FR5 & $\begin{array}{l}\text { Throwing objects, chairs and explosives in the stadium during the } \\
\text { match }\end{array}$ & 0.45 & 4.43 \\
\hline & FR6 & $\begin{array}{l}\text { Lack of respect for the spectators when buying tickets, entry to } \\
\text { and outside the club }\end{array}$ & 0.69 & 4.60 \\
\hline \multirow{4}{*}{ 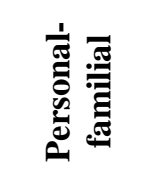 } & SH1 & Inability to attend with family & 0.91 & 7.58 \\
\hline & SH2 & Interruptions from other viewers & 0.44 & 11.19 \\
\hline & SH3 & Declining loyalty to the favorite team & 0.36 & 10.76 \\
\hline & SH4 & Scaring the risks leading to bodily injury & 0.58 & 10.00 \\
\hline \multirow{9}{*}{ 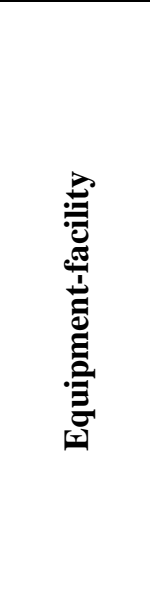 } & T1 & $\begin{array}{l}\text { The lack of incentives such as discounted, half-price and seasonal } \\
\text { tickets for the spectators }\end{array}$ & 0.58 & 10.93 \\
\hline & $\mathbf{T 2}$ & Lack of easy access to stadiums & 0.61 & 10.61 \\
\hline & T3 & Lack of beauty, comfort, security and cleanliness of the stadiums & 0.71 & 10.97 \\
\hline & T4 & Lack of clean bathrooms in the stadiums & 0.80 & 11.12 \\
\hline & T5 & $\begin{array}{l}\text { Difficult, time-consuming, and unsafe exit from the stadiums and } \\
\text { parking lots after the game }\end{array}$ & 0.67 & 9.99 \\
\hline & T6 & Failure to provide proper facilities for children at stadiums & 0.39 & 7.80 \\
\hline & T7 & Lack of appropriate health services at stadiums & 0.50 & 7.65 \\
\hline & T8 & $\begin{array}{l}\text { Shortage, dirt and bustle of immense service returned from the } \\
\text { stadium }\end{array}$ & 0.74 & 11.19 \\
\hline & T9 & Lack of proper facilities for people with disabilities in stadiums & 0.59 & 10.34 \\
\hline
\end{tabular}


Table 3. the first order confirmatory factor analysis model fit indices of the effective factors on reducing the number

\begin{tabular}{ccccccc}
\multicolumn{7}{c}{ of spectators of Iran football Premier League } \\
\hline Fit indices & $\chi^{2} / \mathbf{D F}$ & RMSEA & PNFI & CFI & NFI & RFI \\
\hline Observed values & 2.78 & 0.071 & 0.62 & 0.93 & 0.95 & 0.96 \\
\hline Acceptable values & $<3$ & $<0.08$ & $>0.5$ & $>0.9$ & $>0.9$ & $>0.9$ \\
\hline
\end{tabular}

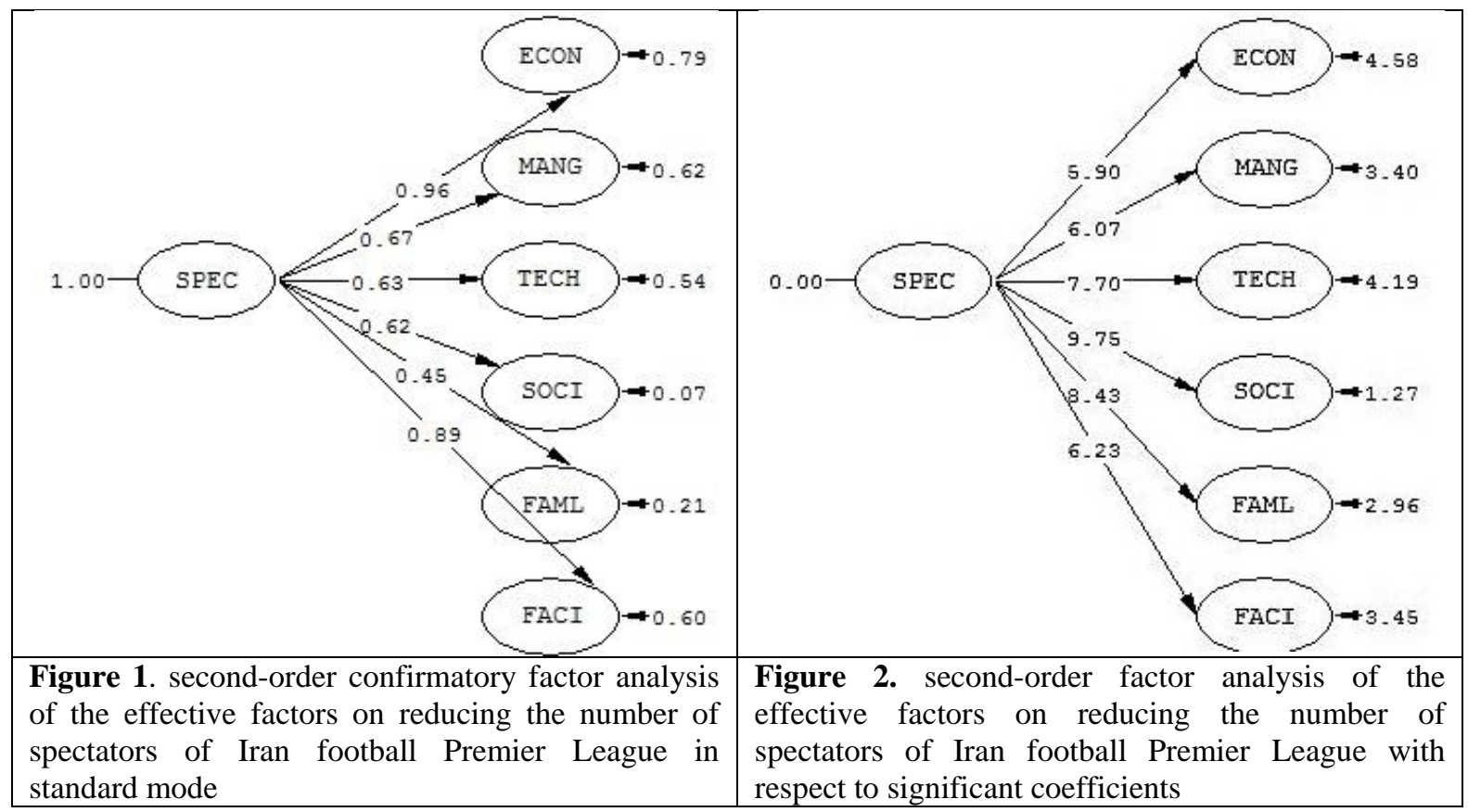

Table 4. the second order confirmatory factor analysis model fit indices of the effective factors on reducing the number of spectators of Iran football Premier League

\begin{tabular}{ccccccc}
\hline Fit indices & $\chi^{2} / \mathbf{D F}$ & RMSEA & PNFI & CFI & NFI & RFI \\
\hline Observed values & 2.48 & 0.071 & 0.59 & 0.95 & 0.97 & 0.96 \\
\hline Acceptable values & $<3$ & $<0.1$ & $>0.5$ & $>0.9$ & $>0.9$ & $>0.9$ \\
\hline
\end{tabular}

\section{DISCUSSION AND CONCLUSION}

Investigating demographic factors is the first step to understand customer behavior in marketing (13). According to the study results, most spectators $(83 / 55 \%)$ were under 30 years representing that the spectators of Iran Football Premier League are young. These results are consistent with those of the study conducted by Ma'soumi (2008) and Elahi (2010) (14, 15). However, they are inconsistent with the results of the study by
Trail et al (2003) and Won and Kitamura (2007) $(16,17)$. This may pertain to cultural differences as well as the entry to the stadiums together with the family in addition to demographic differences.

$69.04 \%$ of the spectators in stadiums were single. This is consistent with the results of some studies conducted in Iran including those by Elahi (2010) and Nikbakhsh, Moshref Javadi, and Mozafari (2008) (14, 18). In Iran, Women cannot go to stadiums which can be 
the reason for lack of desire for married individuals to watch games in the stadiums.

Since most of the spectators were young and students (school or university students) $(4.6 \%)$ in terms of employment status and as the demographic combination of the spectators was young, surveying the income status of the samples showed that most of them had no good financial status and that $82 \%$ of them earned less than 600 dollars a month. Most of them $(41 \%)$ tended to buy the tickets on the Internet which may be due to the availability of the Internet for most people and their familiarity with its advantages.

Given the study results, the effects of all the identified variables on reducing the number of spectators were confirmed and that economic, facility-equipment, managerial, technical, sociocultural, and personal-familial variables had the greatest impacts on reducing the number of spectators in Iran football premier league, respectively.

Economic and facility-equipment factors played a large role in and had the highest effect on reducing the presence of spectators in stadiums and the high cost of tickets for the game among from economic factors and sanitary and cleanliness facilities of stadium among from the components of facilities had the greatest impact on reducing the presence of spectators in stadiums. Fallahi, Asadi, and Khabiri (2009) stated that economic factors such as an increase in the price of tickets and the costs of access to the stadiums had a negative effect on the presence of spectators in stadiums (19). In addition, in their study, Tojjari et al. (2010) stated that economic factors had an important role in encouraging spectators for their presence in stadiums (20). Donihue, Findlay, and Newberry (2007) stated that an increase in the ticket price reduced the presence of spectators (21). On facility-equipment factors, Yusof, See, and Yusof (2008) emphasized the significance of facilities in stadiums and pointed out that paying more attention to these cases was essential for the managers of stadiums and acknowledged that the physical space of the stadium was of utmost importance to satisfy spectators (22). This was also confirmed by other researchers including Hall, O’Mahony, and Vieceli (2010), and Lambrecht, Kaefer, and Ramenofsky (2009) (23, 24). In a study on 486 football spectators, Fallahi, Asadi, and Khabiri (2010) concluded that a high percentage of Iranian spectators were under 25 years and the most important factors affecting their presence were economic factors (the price of ticket and the cost of transportation) and facilitates factors (Beauty, cleanliness, convenience and availability of food) which is quite consistent with the results obtained in this study (25).

After economic and facility-equipment factors, technical and managerial factors had the greatest impact on reducing spectators in stadiums and of management components, lack of appropriate welfare facilities was in the first priority in the games outside home and the poor situation of ticket sale and tournaments at inappropriate time were in the next orders. Of the technical factors, poor judgment of some referees throughout the season was in the first priority and the lack of attractiveness and beauty in the matches and low technical level were in the next priorities. Based on the results of the study, the effect of socio-cultural and personal-family factors was also confirmed on reducing the number of spectators in stadiums. Although these factors were in the last ranks, they had an effect on reducing the number of spectators in stadiums and had been the reasons for their absence. Among socio-cultural factors, lack of enough respect for the spectators when to buy a ticket, to enter in the stadiums, and to leave there were on the first priority and insults and vulgar words, fighting and violent behaviors in stadiums were in the next priorities. Of personal-familial factors, the impossibility of presence of family was the first priority. According to Tojjari et al. (2010), for the spectators, the most important case in socio-cultural factors was that they wanted to have a healthy cultural atmosphere in stadiums and they became sad for the use of curse words by some spectators (20) which is consistent with the results of the studies in this field by Brokaw, Stone, and Jones (2006) (26). In their study, they found that factors 
such as violence, use of obscene words and creation of tension had an inverse relationship with the presence of spectators in stadiums (26). Due to the prohibition of the presence of women in Iranian stadiums, if there is a possibility for the presence of spectators along with their families, in addition to change in the demographics in stadiums, there will be more people in the stadium so that on one hand, the stadium's male atmosphere is changed which helps reduce aggressive behavior (27) and on the other hand, the football clubs will benefit more from that.

\section{APPLICABLE REMARKS}

- According to the study results, it is suggested that sport marketers analyze and evaluate the factors identified in this study and find correct and executable strategies and solutions for them so as to resolve or reduce the rate of problems the spectators face with in order to observe more spectators as well as to have more income for the football clubs.

\section{REFERENCES}

1. Hill B, Christine Green B. Repeat Attendance as a Function of Involvement, Loyalty, and the Sportscape Across Three Football Contexts. Sport Management Review. 2000;3(2):145-62.

2. de Ruyter K, Bloemer J, Peeters P. Merging service quality and service satisfaction. An empirical test of an integrative model. Journal of Economic Psychology. 1997;18(4):387-406.

3. Hansen H, Gauthier R. Factors affecting attendance at professional sport events. Journal of sport management. 1989;3(1):15-32.

4. Nemati N, Tojari F, Zareei A, Ashraf Ganjuyi F. Testing A Theoretical Model Of Factors Affecting Attendance In Spectators Of Soccer's In Iran. Sport Management Review.4(13):107-22 [Article in Farsi].

5. Theodorakis ND, Koustelios A, Robinson L, Barlas A. Moderating role of team identification on the relationship between service quality and repurchase intentions among spectators of professional sports. Managing Service Quality: An International Journal. 2009;19(4):456-73.

6. Elmiri M, Naderian Jahromi M, Soltan Hosseini M, Nasr Esfahani AR, Rahimi M. Factors Influencing Soccer Spectators' Attendance In Professional Soccer Games In Iran. Sport Management (Harakat). 2010(3):61-73 [Article in Farsi].

7. Ghorbani MG. The process of attendance of spectators and its economic impacts on Professional Football League of Iran. Tehran, Iran: Shahid Beheshti University; 2015 [Thesis in Farsi].

8. Hoseini M, Nasr D, Javani V, Salimi M. Determination of the Relative Contribution of Brand Loyalty by Brand Association in Football Premier League of Iran. Journal of Sport Management. 2011;3(9):87-107 [Article in Farsi].

9. Shank MD, Lyberger MR. Sports Marketing: A Strategic Perspective. 5th ed: Taylor \& Francis (Routledge); 2014. $704 \mathrm{p}$.

10. O’Reilly N, Kaplan A, Rahinel R, Nadeau J. "If You Can’t Win, Why Should I Buy a Ticket?”: Hope, Fan Welfare, and Competitive Balance. International Journal of Sport Finance. 2008;3(2):106-18.

11. Robinson MJ, Trail GT. Relationships among spectator gender, motives, points of attachment, and sport preference. Journal of Sport management. 2005;19(1):58-80.

12. Wakefield KL, Sloan HJ. The Effects of Team Loyalty and Selected 8taa Factors on Spectator Attendance. Journal of sport management. 1995;9(2):153-72.

13. Esmaeilpour H. Fundations of Marketing Management. :. 7th ed. Tehran, Iran: Negah-e-Danesh Publication; 2015. [Book in Farsi] 440 p.

14. Elahi A, Sajadi N, Khabiri MA, H. Barriers to develop professional football industry in Iran. Research on Sport Sciences. 2010;7(7):53-68 [Article in Farsi].

15. Ma'soumi S. Survey of motivations and effective factors on attendance in the game of football, : . Tehran, Iran: Tarbiat Modares University; 2008 [Thesis in Farsi].

16. Trail GT, Robinson MJ, Dick RJ, Gillentine AJ. Motives and points of attachment: Fans versus spectators in intercollegiate athletics. Sport Marketing Quarterly. 2003;12(4):217-27.

17. Won J-u, Kitamura K. Comparative analysis of sport consumer motivations between South Korea and Japan. Sport Marketing Quarterly. 2007;16(2):93-105. 
18. Nikbakhsh R, Moshref Javadi B, Mozafari SAA. The Comparison of "Product" Element among Marketing Mix Elements in the Football Pro-League of Iran. Journal of Movement Science \& Sports 2008;5(10):95-105 [Article in Farsi].

19. Fallahi A, Asadi H, Khabiri M. The Comparison of Factors Affecting Casual, Regular and Enthusiastic Spectators' Attendance at Football Pro-league matches. Journal of Sport Management. 2009;1(2):247-516 [Article in Farsi].

20. Tojjari F, Nemati N, Azarbayjani MA, Ghasemi H, Khodayari A. A Case Study of Socioeconomic and Emotional Characteristics of Football Spectators (Esteglal and Pirouzi). Sport Sciences Quarterly. 2010;2(3):109-25 [Article in Farsi].

21. Donihue MR, Findlay DW, Newberry PW. An Analysis of Attendance at Major League Baseball Spring Training Games. Journal of Sports Economics. 2007;8(1):39-61.

22. Yusof A, See LH, Yusof A. Spectator perceptions of physical facility and team quality: A study of a Malaysian super league soccer match. Research Journal of International Studies. 2008;8(2):132-40.

23. Hall J, O’Mahony B, Vieceli J. An empirical model of attendance factors at major sporting events. International Journal of Hospitality Management. 2010;29(2):328-34.

24. Lambrecht KW, Kaefer F, Ramenofsky SD. Sportscape factors influencing spectator attendance and satisfaction at a professional golf association tournament. Sport Marketing Quarterly. 2009;18(3):165-72.

25. Fallahi A, Asadi H, Khabiri M. Exploratory study of factors affecting attendance of Iran football pro-league spectators. Research on Sport Sciences. 2010;7(7):33-52 [Article in Farsi].

26. Brokaw A, Stone GW, Jones MA. A Model of the Factors Contributing to Fan Support at Small-College Athletic Events. The Sport Journal. 2006(33):online.

27. Rahmaninia F, Ramezaninejad R, Fazli Darzi A. The Effects of Presence of Male and Female Spectators on the Level of Disclosure of Aggressive Behavior among Athletes. Harakat. 2006(29):137-46 [Article in Farsi].

Khadem, A. R. Azghadi, Boroumand, M. R., Salari, M. H. (2016). Ann Appl Sport Sci, 4(2): 59-66. 